\title{
Time lags between the deposition and meiobenthic assimilation of phytodetritus
}

\author{
David T. Rudnick* \\ Marine Ecosystems Research Laboratory, Graduate School of Oceanography, University of Rhode Island, Kingston, Rhode \\ Island 02881, USA
}

\begin{abstract}
The importance of freshly produced phytoplankton detritus in the diet of marine meiobenthos in a soft-bottom community was examined in a $14 \mathrm{~m}^{3}$ microcosm. Radiolabelled phytodetritus was continuously produced in the water column from January to June by the addition of ${ }^{14} \mathrm{C}$-bicarbonate. The specific activity of organic carbon in plankton, sediment and meiobenthos was measured during this time. All meiobenthos reached specific activities higher than that of the sediment; recently produced, labelled detritus was more readily assimilated than older sedimentary carbon. However, the proportion of assimilated carbon that was apparently derived from labelled detritus differed greatly between 2 distinct faunal groups found in the top $5 \mathrm{~mm}$ of sediment. One group, dominated by harpacticoid copepods, reached specific activities identical to that of the phytoplankton. These fauna thus almost exclusively assimilated labelled detritus, and for harpacticoids there was a lag of less than 2 mo between detrital deposition and assimilation. The second group included most other meiobenthic taxa and, by late May, still had remarkably low specific activities - from 10 to $30 \%$ of phytoplankton values. It appears that most of the organic carbon in the diet of these fauna had been produced prior to January. I suggest that these 2 meiobenthic groupings were segregated by depth in the surface millimeters and that the low specific activity fauna utilized a large, buried reservoir of older detritus.
\end{abstract}

\section{INTRODUCTION}

A recurrent seasonal cycle of meiobenthic and macrobenthic abundance and biomass occurs in the muddy sediments of middle Narragansett Bay, Rhode Island (Grassle et al. 1985, Rudnick et al. 1985). Maxima are found in late spring and early summer and minima are reached by early autumn. This seasonal pattern has been attributed primarily to food availability; Rudnick et al. (1985) proposed that in this phytoplankton-based food web (Oviatt \& Nixon 1975, Gearing et al. 1984), fauna thrived in the spring and early summer on detritus that was derived from winter and spring diatom blooms and had accumulated in the sediment. It was suggested that summer and autumn faunal decreases were associated with the depletion of this stored detritus.

The possibility of seasonal time lags in the assimilation of phytodetritus by benthic fauna is surprising because phytoplankton lack complex structural materi-

\footnotetext{
- Present address: Section of Ecology and Systematics and the Ecosystems Research Center, Cornell University, Ithaca, New York 14853, USA
}

als, such as lignin; assimilation and mineralization of such a 'labile' substrate by benthic bacteria and fauna should be rapid (Tenore et al. 1982). However, mechanisms which may delay the mineralization of phytodetritus have been proposed. These include the depression of metabolic activity by low temperatures (Pomeroy \& Deibel 1986), by anoxic conditions or by the accumulation of inhibitory metabolic endproducts in subsurface sediments (Howarth \& Hobbie 1982), or the formation of more complex and refractory 'geopolymers' from simpler compounds (Rice 1982, Cronin \& Morris 1983).

Since it is not currently possible to trace the fate of a given parcel of organic matter in the field, it is not known whether sedimentary phytodetritus is indeed seasonally stored in nature, and the phenology of phytodetrital assimilation by benthic fauna has not been studied. However, with the advent of large marine microcosms (Grice \& Reeve 1982), long-term, realistic studies of the fate of radiolabelled detritus are possible. Such a study, where the water column of a large microcosm (Fig. 1) was labelled with ${ }^{14} \mathrm{C}$-bicarbonate for $6 \mathrm{mo}$, was conducted at the Marine Ecosystems Research Laboratory (MERL). Results pertaining to the 
carbon budget of the microcosm have been presented in Rudnick \& Oviatt (1986). The major finding of this budget was that a large proportion of the labelled phytoplankton detritus that was deposited on and mixed into the sediment was not immediately mineralized by the benthos. Between January and July, $14.5 \mathrm{~g} \mathrm{C} \mathrm{m}^{-2}$ of labelled organic carbon, or $15 \%$ of net daytime primary production and roughly $50 \%$ of gross sedimentation, accumulated in the sediment.

In this paper, I shall examine the age of the food resources that were assimilated by meiobenthos in this microcosm study. The in situ production of radiolabelled phytoplankton supplied a temporally marked pool of detritus for benthic consumers. The analysis of faunal specific activity provided a means of assessing the extent to which different fauna assimilated recent, labelled detritus versus older, non-labelled detritus. This approach is qualitatively similar to investigations that compare the stable isotope ratios of fauna and different food sources (Fry \& Sherr 1984), but this study will compare the radioisotope ratios of fauna and pools of organic matter that are from a single (phytoplankton) source, but are of different ages.

\section{METHODS}

Details of the design and operation of the radiocarbon study were given in Rudnick \& Oviatt (1986). Briefly, a single addition of $1.6 \mathrm{mCi}$ of ${ }^{14} \mathrm{C}$-bicarbonate

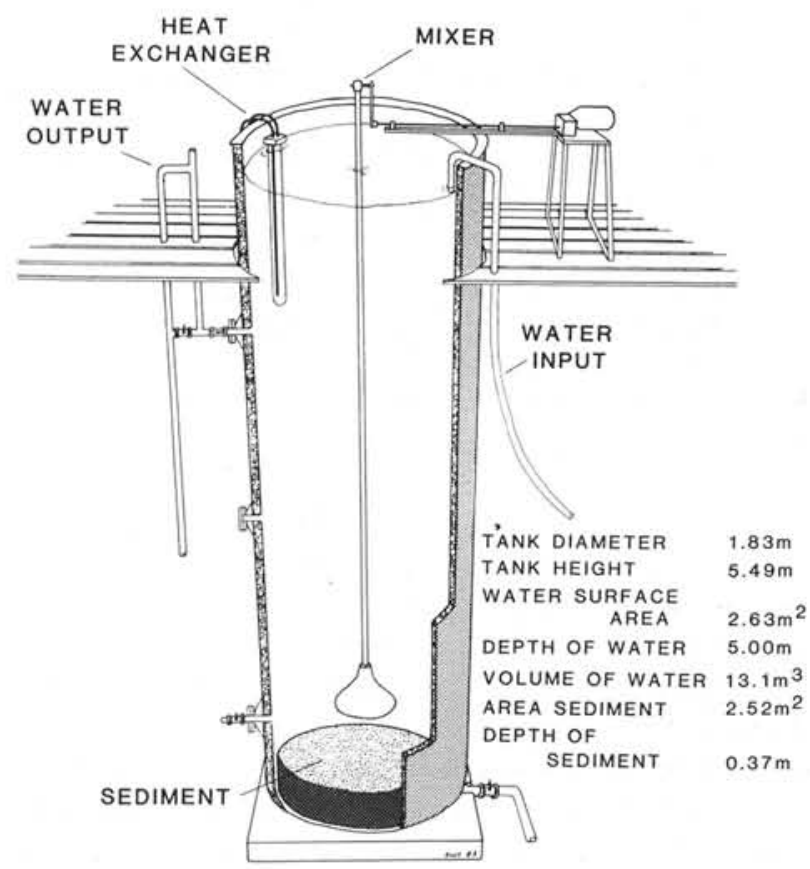

Fig. 1. A MERL tank. During this study, there was no input or output of water through the plumbing system. Drawing by Eric Klos was made to the $13 \mathrm{~m}^{3}$ water column of a microcosm (Fig. 1) of the Marine Ecosystems Research Laboratory (MERL) on 6 January 1981. For about $6 \mathrm{mo}$, the production of organic carbon by phytoplankton and the fate of this organic carbon in the water column and sediment was measured. There was no exchange of seawater with Narragansett Bay during this time. The water column of the tank was drained and refilled with bay water on 19 June.

Except for the lack of seawater exchange, the microcosm was constructed and maintained in the same way as other MERL microcosms. The tank contained $13 \mathrm{~m}^{3}$ of Narragansett Bay water (about $30 \%$ salinity) over a $37 \mathrm{~cm}$ deep sediment tray which was filled with midNarragansett Bay silt-clay sediment using a $0.25 \mathrm{~m}^{2}$ USNEL box core (Hunt \& Smith 1983). Maintenance included the control of temperature within $2 \mathrm{C}^{\circ}$ of Narragansett Bay water, wall cleaning, and water column mixing. This mixing yields particle loads and fluxes similar to those of the bay (Oviatt 1981, Santschi et al. 1982). With a water column height of $5 \mathrm{~m}$, suspended particles are sufficient to reduce light at the bottom to less than $1 \%$ of surface illumination and thus maintain a heterotrophic community (Oviatt et al. 1986). Generally, the microcosms mimic the biological and chemical characteristics of the bay, including pelagic and benthic species composition, primary productivity, pelagic and benthic respiration, and nutrient concentrations and fluxes (Pilson et al. 1980, Grassle et al. 1981, Oviatt et al. 1981, Frithsen 1984, Pilson 1985). In a previous 8 mo experiment, these characteristics did not differ when microcosms were operated with or without seawater exchange with the bay (Pilson et al. 1980, Pilson 1985).

The sediment was sampled 9 times between 6 January and 23 May, using 2 corers $\left(5 \mathrm{~cm}^{2}\right.$ and $\left.10 \mathrm{~cm}^{2}\right)$ as in Frithsen et al. (1983). Six cores were taken with each corer per sampling time and sliced in depth layers. The smaller cores were used for the analysis of total organic carbon and organic ${ }^{14} \mathrm{C}$ in the bulk sediment. Details of these procedures are given in Rudnick \& Oviatt (1986). Subsamples were taken from the larger cores for these analyses as well, but most of the sediment was used for the analysis of faunal specific activity.

Live meiobenthos (defined as metazoans and foraminiferans that pass through a $500 \mu \mathrm{m}$ mesh and are retained on a $40 \mu \mathrm{m}$ mesh) were extracted from pooled cores by sieving through 500, 300, 200 and $100 \mu \mathrm{m}$ mesh sieves. Fauna in the 200 and $100 \mu \mathrm{m}$ fractions were first concentrated from other particles by centrifuging at $1000 \mathrm{rpm}$ for $3 \mathrm{~min}$ in a $25 \%$ (V/V) solution of Ludox TM (E.I. duPont) in filtered seawater (the carbon content of Ludox was only $0.02 \%$ of dry weight) as in Bowen et al. (1972) and deJonge \& Bouwman (1977). 
Meiobenthos were sorted to readily recognizable taxonomic groups (e.g. nematodes, turbellarians). The determination of living versus dead foraminiferans was based on the presence of a light brown-green pigment inside the test; in a separate set of samples, all individuals that were clearly pigmented were also brightly stained by rose bengal. Fauna were cleaned of all attached debris, placed in dishes with filtered seawater $\left(4^{\circ} \mathrm{C}\right)$ for 12 to $24 \mathrm{~h}$ to allow for defecation, cleaned again, put on precombusted glass fiber filters, and frozen $\left(-20^{\circ} \mathrm{C}\right)$. Each sample contained about $100 \mu \mathrm{g} \mathrm{C}$ and up to 644 individuals. When possible, triplicate pooled samples were collected.

The specific activity of organic carbon in each sample was measured directly as in Rudnick \& Oviatt (1986). Most samples were prepared for analysis by drying at $60^{\circ} \mathrm{C}$ and then fuming with $\mathrm{HCl}$ to remove inorganic carbon. Foraminiferans and ostracods, however, were placed in pre-combusted crucibles, soaked in $6 \mathrm{~N}$ phosphoric acid, dried at $60^{\circ} \mathrm{C}$, and then combusted in the same crucible so that no dissolved organic carbon was lost (Rudnick \& Oviatt 1986). Samples were oxidized at $950^{\circ} \mathrm{C}$ in a stream $\left(11 \mathrm{~min}^{-1}\right)$ of $\mathrm{CO}_{2}$-free oxygen, and the $\mathrm{CO}_{2}$ that evolved from the samples was measured as it flowed through an Horiba PIR-2000 infrared analyzer. The ${ }^{14} \mathrm{C}$ activity of this $\mathrm{CO}_{2}$ was measured by bubbling the effluent gas through phenethylamine in a vigreaux column, which trapped the $\mathrm{CO}_{2}$, then rinsing the column with scintillation cocktail, and counting. The precision (mean coefficient of variation for glucose standards) and accuracy (differences with 2 other elemental analyzers) of the total carbon analysis was about $3 \%$, and ${ }^{14} \mathrm{C}$ recovery from the combustion of standard radiolabelled materials was $97 \%$ (see Rudnick \& Oviatt 1986 for details).

\section{RESULTS}

\section{Specific activity of detrital food sources}

The mean specific activity of phytoplankton carbon ranged from 11.2 DPM $(\mu \mathrm{g} \mathrm{C})^{-1}$ during January to 9.2 DPM $(\mu \mathrm{g} \mathrm{C})^{-1}$ during April and May (Rudnick \& Oviatt 1986). These values were derived from estimates of dissolved inorganic carbon specific activity and verified by measurements of organic carbon in suspended particles (Table 2 in Rudnick \& Oviatt 1986).

As high specific activity phytodetritus settled onto the sediment surface and mixed with non-labelled particles, the specific activity of the sediment increased (Fig. 2). This increase was rapid in the top $0.5 \mathrm{~cm}$ layer, reaching 0.2 DPM $(\mu \mathrm{gC})^{-1}$ after $18 \mathrm{~d}$. The specific activity of total organic carbon in this layer then remained near $0.2 \mathrm{DPM}(\mu \mathrm{g} \mathrm{C})^{-1}$ for the duration of the

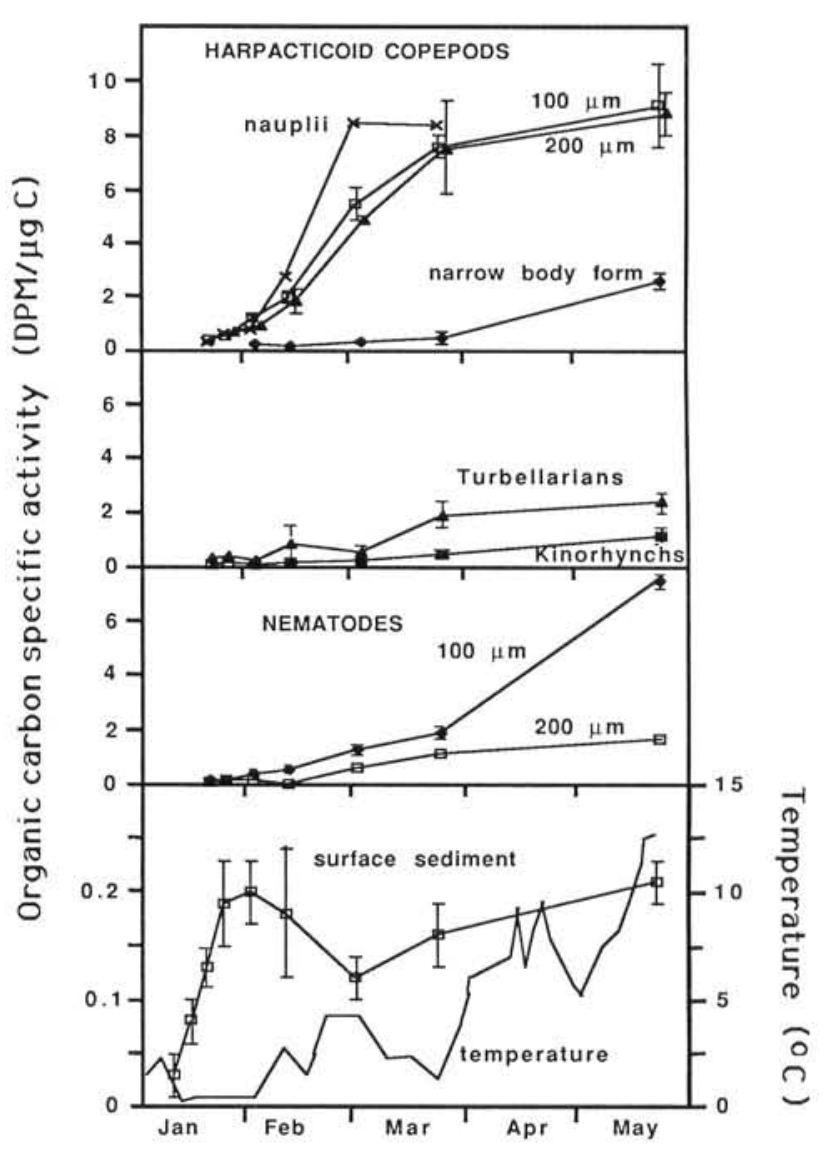

Fig. 2. Time series of meiobenthic and sediment specific activity $( \pm 1 \mathrm{SE}$ ) in the top $5 \mathrm{~mm}$ of sediment, and water temperature, up to 23 May. ${ }^{14} \mathrm{C}$-bicarbonate was added to the tank on 6 January. Faunal sieve size fractions are given for harpacticoid copepods and nematodes. Harpacticoids with a narrow body form were collected and combusted separately and are not included in the $100 \mu \mathrm{m}$ and $200 \mu \mathrm{m}$ data

study. These values were low compared to phytoplankton values because of the high concentration (about $2 \%$ of dry weight) of sedimentary organic carbon (Rudnick \& Oviatt 1986).

\section{Meiobenthic specific activity}

Two groups of benthic fauna were distinguished in the top $0.5 \mathrm{~cm}$ of sediment on the basis of their organic carbon specific activity (Fig. 3). By 23 May, one group of fauna reached high specific activities (from 6.2 to 8.9 DPM $\left[\mu \mathrm{g} \mathrm{C}^{-1}\right.$ ) that were similar to those of the phytoplankton; differences were not significant $(p>0.05$, using both 2-tailed Student's $t$-test and Mann-Whitney $U$-test). A second group of fauna had much lower specific activities (from 1.0 to $3.2 \mathrm{DPM}[\mu \mathrm{g} \mathrm{C}]^{-1}$ ). While these values were significantly $(p<0.01,2$-tailed $t$ and $U$-tests) higher than that of the surface sediment, they 


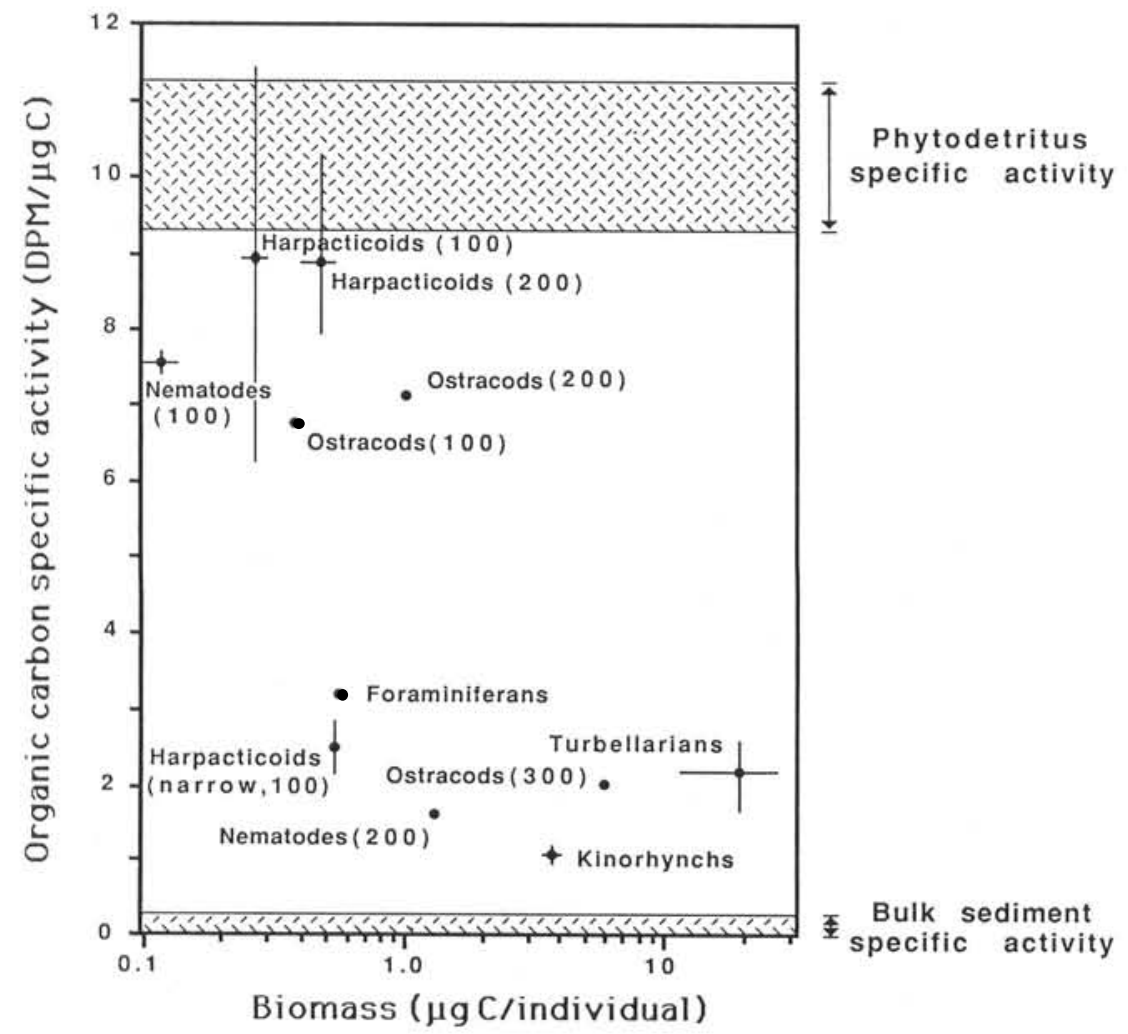

Fig. 3. Meiobenthic specific activity from the top $5 \mathrm{~mm}$ of sediment on $23 \mathrm{May}$, as a function of individual body size (all bars are ranges, from pooled samples). The specific activity range, for the entire study, of 2 potential benthic food sources, labelled phytoplankton detritus and total organic carbon in the sediment (a mixture of this detritus and unlabelled organic matter), is noted by the stippled areas. Sieve size fraction (mesh in $\mu \mathrm{m}$ ) from which meiofauna were extracted is noted parenthetically

were still less than $30 \%$ of phytoplankton values in late May. No fauna had values between 3.2 and 6.2 DPM $(\mu \mathrm{gC})^{-1}$ and each of the 3 taxa in the low specific activity group that had replicate samples was significantly different ( $p<0.05,2$-tailed $t$-tests) from each of the replicated high specific activity taxa $(100 \mu \mathrm{m}$ nematodes and pooled harpacticoid copepod size fractions). Within the high and the low specific activity groupings, specific activities of the taxa were not significantly different and were independent of body size over a 100 -fold size range (Fig. 3).

Harpacticoid copepods rapidly reached the highest specific activity level of any common benthic fauna (Figs. 2 and 3). Both the 100 and $200 \mu \mathrm{m}$ size fractions attained specific activities similar to that of the phytoplankton (about $10 \mathrm{DPM}\left[\mu \mathrm{g} \mathrm{C}^{-1}\right.$ ) within $2 \mathrm{mo}$ of the initial pulse of labelled deposits to the sediment (Fig. 2). Harpacticoid nauplii reached the same specific activity level by 3 March.

Harpacticoid copepods that had a relatively narrow body form (primarily Enhydrosoma spp.) were collected separately from the remaining species, which had a more robust body form (most commonly Microarthridion littorale). In contrast to these more robust species, the narrow bodied species were found to have very low specific activities, with values below 2.8 DPM $(\mu \mathrm{g} \mathrm{C})^{-1}$ (Fig. 2).

Kinorhynchs and turbellarians also had low specific

Table 1. Depth profiles of meiobenthic specific activity (SA) on 23 May and sediment SA on 23 March and 23 May. The sediment ratio equals the tissue SA divided by the May sediment SA. Sedimentary organic carbon had low SA values because detritus with SA values of about 10 DPM ( $\mu \mathrm{g} \mathrm{C}^{-1}$ was diluted by unlabelled sedimentary organic matter. Standard errors (SE) are missing $(-)$ for most tissue samples because only enough biomass could be collected for one sample

\begin{tabular}{|c|c|c|c|c|c|c|c|c|c|c|c|c|}
\hline \multirow{3}{*}{$\begin{array}{l}\text { Depth } \\
(\mathrm{cm})\end{array}$} & \multirow{2}{*}{\multicolumn{2}{|c|}{$\begin{array}{c}\text { March } \\
\text { sediment SA } \\
\left(\mathrm{DPM}[\mu \mathrm{g} \mathrm{C}]^{-1}\right)\end{array}$}} & \multirow{2}{*}{\multicolumn{2}{|c|}{$\begin{array}{c}\text { May } \\
\text { sediment SA } \\
\left(\mathrm{DPM}[\mu \mathrm{g} \mathrm{C}]^{-1}\right)\end{array}$}} & \multicolumn{4}{|c|}{ Nematoda } & \multicolumn{4}{|c|}{ Foraminifera } \\
\hline & & & & & \multirow{2}{*}{$\begin{array}{c}\text { Sieve } \\
\text { fraction } \\
(\mu \mathrm{m})\end{array}$} & \multirow{2}{*}{$\begin{array}{l}\text { Mean SA } \\
(\mathrm{DPM} \\
\left.[\mu \mathrm{g} \mathrm{C}]^{-1}\right)\end{array}$} & \multirow[t]{2}{*}{$\mathrm{SE}$} & \multirow{2}{*}{$\begin{array}{l}\text { Sedi- } \\
\text { ment } \\
\text { ratio }\end{array}$} & \multirow{2}{*}{$\begin{array}{c}\text { Sieve } \\
\text { fraction } \\
(\mu \mathrm{m})\end{array}$} & \multirow{2}{*}{$\begin{array}{l}\text { Mean SA } \\
(\mathrm{DPM} \\
{\left[\mu \mathrm{g} \mathrm{C}^{-1}\right)}\end{array}$} & \multirow[t]{2}{*}{ SE } & \multirow{2}{*}{$\begin{array}{l}\text { Sedi- } \\
\text { ment } \\
\text { ratio }\end{array}$} \\
\hline & Mean & SE & Mean & $\mathrm{SE}$ & & & & & & & & \\
\hline \multirow[t]{2}{*}{$0-0.5$} & 0.16 & 0.03 & 0.21 & 0.02 & 200 & 1.6 & - & 8 & $200-300$ & 3.2 & - & 15 \\
\hline & & & & & 100 & 7.6 & 0.1 & 36 & & & & \\
\hline $0.5-1$ & 0.09 & 0.02 & 0.06 & 0.03 & 100 & 2.8 & - & 47 & $200-300$ & 0.7 & - & 12 \\
\hline $1-2$ & 0.05 & 0.01 & 0.07 & 0.02 & 100 & 1.5 & - & 21 & $200-300$ & 0.3 & - & 4 \\
\hline $2-6$ & 0.03 & 0.02 & 0.07 & 0.02 & 100 & 1.6 & - & 27 & 300 & 0.2 & - & 3 \\
\hline
\end{tabular}


activities throughout the study (Fig. 2), with kinorhynch values remaining below 1.1 DPM $(\mu \mathrm{g} \mathrm{C})^{-1}$. Nematodes and ostracods had specific activities that varied with size; the $200 \mu \mathrm{m}$ fraction of nematodes and the $300 \mu \mathrm{m}$ fraction of ostracods were low at the end of May, while smaller fractions reached about 7 DPM ( $\mu$ g C $)^{-1}$ (Fig. 2).

\section{Meiobenthic specific activity with depth}

Nematodes and foraminiferans were the only meiobenthos that were commonly found below the top $0.5 \mathrm{~cm}$ layer of sediment. Although only enough biomass could be collected on 23 May for a single sample from each layer, faunal specific activity values in each layer's samples were similar (Table 1). Sediment specific activity was likewise nearly uniform with depth in May. While tissue values were very low in deeper sediment layers, especially for foraminiferans, all these values were higher than sediment values. For subsurface nematodes, the ratio of tissue to sediment specific activity (Table 1 ) was near the ratio range (32 to 42) of the high specific activity faunal group in the surface sediment layer in May (Fig. 3). However, deep foraminiferans had extremely low ratios which were below the ratio range ( 5 to 15 ) of the low specific activity faunal group in the surface layer.

\section{DISCUSSION}

The finding of high specific activity meiobenthos, such as the harpacticoid copepods, unambiguously reveals the age of their detrital food source. Clearly, these fauna almost exclusively assimilated organic carbon that had been recently produced by phytoplankton. For harpacticoids, 'recently' can be constrainted to a period of about 2 mo since these fauna reached nearly the same specific activity as the phytoplankton by 23 March.

A second finding which can also be unambiguously interpreted is that by 23 May, the specific activity of all fauna, measured to a depth of $6 \mathrm{~cm}$ in the sediment, exceeded that of the bulk sedimentary carbon (i.e. tissue to sediment ratios were $>1$ ). Clearly, labelled organic matter was more readily assimilated than the older, unlabelled organic matter. (This distinguishes the source of assimilated carbon and not whether nonliving carbon or intermediate, microbial biomass was assimilated.) If recent and older carbon had been qualitatively identical (for both fauna and microbiota), fauna would have derived their tissues' carbon in proportion to its abundance in the sediment - about $2 \%$ from recent, labelled organic carbon and $98 \%$ from older, unlabelled organic carbon in the top $0.5 \mathrm{~cm}$ layer at the end of May. Thus, preferential assimilation of labelled organic matter, whether via ingestive or digestive processes, occurred. Since much of the organic carbon in the top centimeters of coastal sediments can be several thousand years old (Benoit et al. 1979), this finding is not surprising, and confirms a long standing supposition of benthic ecologists (Marshall 1972).

What is more surprising, and must be cautiously interpreted, is that so many meiobenthic taxa in the top $5 \mathrm{~mm}$, after months of labelled phytodetrital deposition, still had such low specific activities - from 10 to $30 \%$ of phytoplankton values. It seems likely that these fauna had such low values because most ( 70 to $90 \%$ ) of the organic carbon in their diet was derived from organic matter that had been produced prior to January. While these fauna preferentially assimilated radiolabelled organic matter (i.e. they had specific activity values $>0.2$ DPM $[\mu \mathrm{g} \mathrm{C}]^{-1}$ in the surface sediment), this preference was far from exclusive. Furthermore, if this interpretation of food source age is accurate, then the occurrence of 2 distinct specific activity groupings of meiobenthos (Fig. 3 ) is evidence for the existence of 2 distinct food webs within the top $5 \mathrm{~mm}$ of a soft-bottom community, where the age of the detrital food sources of the groups differs.

\section{Assumptions in the interpretation of faunal specific activities}

The identity of detrital food sources can be accurately inferred from measurements of faunal specific activity if 3 assumptions were valid: (1) the specific activity of an organism's food was constant; (2) an organism fed on this food for a time span that exceeded the replacement (turnover) time of the organism's carbon; (3) the specific activity of an organic carbon molecule was conservative.

The specific activity of an organism's food was a function of the specific activity of the labelled, recent detritus, the relative abundance of these particles as they mixed with non-labelled particles, and the relative digestibility of these 2 particle types. The first assumption was violated because none of these aspects was constant. However, the interpretation of faunal specific activities is not greatly affected for 2 reasons. First, changes in the specific activity of labelled detritus during the study were small, with phytoplankton specific aciivity dropping from about 11 to 9 DPM $\left(\mu \mathrm{g} \mathrm{C}^{-1}\right.$ between January and the end of May (Rudnick \& Oviatt 1986). Second, the quantity of labelled organic matter in the top $0.5 \mathrm{~cm}$ of sediment was relatively constant from 30 January to 23 May (Fig. 2) and in the top $2 \mathrm{~cm}$ of sediment from 23 March to 23 May (Table 1; Fig. 4 in Rudnick \& Oviatt 1986). During a time of rising 
temperature (Fig. 2) and, presumably, increasing rates of body carbon turnover, the availability of labelled food was nearly constant.

The second assumption probably requires the closest scrutiny of these assumptions. If an organism's carbon pool had only been partially replaced during the study, the tissue specific activity would be less than 10 DPM $\left(\mu \mathrm{g} \mathrm{C}^{-1}\right.$, even if labelled particles of this specific activity were the exclusive food source. It is unlikely that this critical assumption was violated for the surface meiobenthos; because of their small size $(<30 \mu \mathrm{g} \mathrm{C}$ each, Fig.3), rapid turnover is expected. Three independent lines of evidence are in support of this expectation. First, some fauna (harpacticoid copepods) exhibited such a rapid turnover, reaching a specific activity asymptote near 10 DPM ( $\mu \mathrm{g} \mathrm{C}^{-1}$ by 23 March (Fig. 2), with temperatures below $4{ }^{\circ} \mathrm{C}$. Second, laboratory studies of body carbon turnover for invertebrates with $\leq 100 \mu \mathrm{g} \mathrm{C}$ (Sorokin 1966, Lee et al. 1971, Conover \& Francis 1973, Lampert 1975, Copping \& Lorenzen 1980) have found carbon turnover times of $\leq 6 \mathrm{~d}$ at $20^{\circ} \mathrm{C}$. Thus, at least 1 turnover would have occurred during April (mean temperature $=7^{\circ} \mathrm{C}$ ), even with a $Q_{10}$ as high as 4. Based on such studies (Wetzel 1976, Fry \& Arnold 1982), even organisms as large as $10^{5} \mu \mathrm{g} \mathrm{C}$ would be expected to complete a turnover of their body carbon between 23 March and 23 May (for $Q_{10}=2$ ). Third, new generations of meiobenthic populations are generally observed during the spring (Coull \& Bell 1979) and 2- to 10-fold increases in the abundance and biomass of almost all meiobenthic taxa have been measured in the spring (temperatures $\leq 10^{\circ} \mathrm{C}$ ) in Narragansett Bay (Rudnick et al. 1985) and the MERL microcosms (Frithsen 1984, Widbom \& Elmgren 1988).

The last assumption is likely to be true because isotopic fractionation during organic degradation or food web transfers is minimal (about $1 \%$ per transfer; Fry \& Sherr 1984). However, a complication that should be considered is the separation of carbon and energy flow during sulfate reduction (Howarth \& Teal 1980), with the secondary fixation of organic carbon by chemolithoautotrophs in the sediment. Fauna that fed on these bacteria would attain the specific activity of this fixed carbon, which would be determined by the specific activity of dissolved inorganic carbon (DIC) in the pore waters. For near surface fauna (certainly in the top $5 \mathrm{~mm}$ ), the specific activity of pore water DIC was probably similar to that of the water column, since pore water exchange rates were probably rapid. (With lower particle mixing rates than were estimated by Rudnick \& Oviatt (1986), Luedtke \& Bender (1979) measured a 'biological pumping rate' of $0.7 \mathrm{~cm}^{3} \mathrm{~cm}^{-2} \mathrm{~d}^{-1}$ across the sediment-water interface of Narragansett Bay sediments.) Furthermore, most chemolithoautotroph biomass is expected to be in the top centimeter of sediment since these bacteria are only found near the oxic-anoxic interface (Jørgensen 1977), which is generally expected to be within the top $5 \mathrm{~mm}$ of these (Kelly 1983) and other coastal muds (Jørgensen \& Revsbech 1985).

\section{Two food webs segregated by depth}

Given these assumptions, the occurrence of high and low specific activity faunal groups (Fig. 3) appears to reflect the existence of 2 distinct food webs within the upper $5 \mathrm{~mm}$ of the microcosm's mud. The age of detrital food sources, delineated by the radiocarbon marker, clearly differed for these 2 faunal groups. Fauna with specific activities that were similar to phytoplankton specific activities predominantly assimilated freshly produced organic matter. Fauna with much lower specific activities predominantly assimilated older, non-labelled organic matter.

The occurrence of 2 distinct faunal groups is probably attributable to differences in feeding behavior, with high specific activity fauna feeding at the sediment-water interface and low specific activity fauna feeding beneath this layer. Whitlatch (1980) has also emphasized the behavioral distinction between surface and subsurface deposit feeding polychaetes. The inclusion of meiobenthos in this study indicates that this distinction occurs across the entire soft-bottom community and that the spatial scale of the feeding separation is only a few millimeters of depth.

In coastal muds, chemical and physical gradients are very steep in the top few millimeters. At the sedimentwater interface, most detritus is in the form of flocculent particles. These particles may be phytal debris or organic-mineral aggregates that are common to surface sediments and the suspended load of coastal waters (Johnson 1974, Rhoads et al. 1984). Their nature and dynamics, however, have not been well documented because they are inadequately sampled by many standard sediment collection techniques (Frithsen et al. 1983). Beneath the surface flocculent layer, detrital particles are generally in a compacted form within fecal pellets or bulk sediment (Moore 1931, Young 1971, Rhoads 1974) and are certainly, on average, of greater age and poorer nutritional quality than surface particles.

The chemical habitat also changes drastically in the top few millimeters, with a transition from oxic surface water to anoxic pore waters (Aller 1982, Jørgensen \& Revsbech 1985). The depletion of molecular oxygen in the top millimeters may be particularly important, as the high specific activity group included most crustaceans (harpacticoids and ostracods) and few other taxa; crustaceans are generally less tolerant of anoxia than other meiobenthos (Tietjen 1969). 
Further evidence for the segregation of faunal groups by depth is the specific activity differences within the harpacticoid and nematode groupings. Harpacticoid copepods with relatively narrow body forms (mostly Enhydrosoma spp.) had low specific activities (Fig. 2) while harpacticoids with a more robust form (mostly Microarthridion littorale) had high specific activities. Narrower forms are better suited for burrowing (Hicks \& Coull 1983); Warwick \& Gee (1984) found that $M$. littorale was mostly in the top $1 \mathrm{~mm}$ of soft sediment and limited to the top $3 \mathrm{~mm}$, while Enhydrosoma was found mostly between 2 and $4 \mathrm{~mm}$, but as deep as $13 \mathrm{~mm}$. Likewise, the difference in specific activity between size fractions of nematodes probably reflects different feeding depths; nematodes found in the surface flocculent layer are generally smaller than subsurface nematodes (Jensen 1983) and the $100 \mu \mathrm{m}$ size fraction in the surface $5 \mathrm{~mm}$ in May had exceptionally small individuals (mean of $0.10 \mu \mathrm{g} \mathrm{C}, \mathrm{SD}=0.02$, compared to $0.34 \mu \mathrm{g} \mathrm{C}, \mathrm{SD}=0.13$, in 18 earlier samples).

\section{Ages of detrital food sources}

The phytodetritus that was consumed by high specific activity fauna through the end of May was labelled, and therefore less than 5 mo old. For harpacticoids, non-labelled food sources were a minor dietary component within $2 \mathrm{mo}$ of the radiocarbon addition.

Low specific activity fauna consumed a mixture of recently produced, labelled detritus and older, nonlabelled detritus. The age of this latter food source is unknown, but a large portion could have been produced in late December, prior to the radiocarbon addition, when a large diatom bloom yielded a deposit of between 18 and $31 \mathrm{~g} \mathrm{C} \mathrm{m}^{-2}$ to the sediment (Rudnick \& Oviatt 1986). However, it is likely that 'old' organic matter (i.e. fixed prior to this diatom bloom) was also assimilated, since low faunal specific activities (1.1 to 3.2 DPM $\left[\mu \mathrm{g} \mathrm{C}^{-1}\right.$ ) in the surface $5 \mathrm{~mm}$ in May were much lower than the calculated minimum specific activity of 'fresh' detritus (a combination of labelled plus December bloom detritus, yielding 4.9 DPM $\left[\mu \mathrm{Cl}^{-1}\right)$. This minimum value was calculated assuming that $25 \mathrm{~g} \mathrm{C} \mathrm{m}^{-2}$ from the December bloom remained on 23 May (a gross overestimate) and was evenly mixed to $10 \mathrm{~cm}$ (based on estimated bioturbation rates in Rudnick \& Oviatt 1986). Since May faunal specific activities were about half of the 'fresh' detritus value, it appears that roughly half of the assimilated organic carbon had been produced prior to late December.

This older carbon was at least as important in the diet of deeper dwelling fauna as for surface fauna. Nematode specific activity below $1 \mathrm{~cm}$ (Table 1 ) was roughly half the estimated specific activity value of buried 'fresh' detritus (about 3 DPM $\left[\mu \mathrm{g} \mathrm{C}^{-1}\right.$, calculated as above), while foraminiferans had about $10 \%$ of this value, indicating that they assimilated roughly $90 \%$ 'old' carbon.

While these startling estimates are not quantitatively reliable, they clearly show that a portion of the bulk carbon of coastal muds, which is often termed 'refractory', is not only 'available' carbon but can also be of considerable importance to much of the benthic community. This conclusion is consistent with estimates of the importance of non-living organic matter in the diet of macrobenthic deposit feeders (Cammen 1980, Lopez \& Levinton 1987) and with diagenetic studies in the laboratory (Kelly \& Nixon 1984, Westrich \& Berner 1984, Grant \& Hargrave 1987), which have shown that available organic matter are present in coastal sediments in sufficient quantity to sustain mineralization rates (primarily bacterial) for many months in the absence of particulate inputs, although these rates may decline in an exponential manner (Westrich \& Berner 1984). The results of my study have provided evidence that some organic carbon in bulk sediments are not only available for microbial mineralization for many months, but also that this carbon can flow, in situ, through the entire subsurface food web.

\section{Food resource stability and trophic structure}

In both coastal and oceanic ecosystems, the sinking of particles from pelagic to benthic communities has been found to be a seasonally varying phenomenon, with much of the annual organic input derived from winter and spring diatom blooms (Elmgren 1978, Billet et al. 1983, Smetacek 1984, Hargrave \& Phillips 1986). With minimal zooplankton grazing and bacterial activity at this time, most phytodetrital particles settle to the sediment nearly intact (Durbin \& Durbin 1981, Hobbie \& Cole 1984, Smetacek 1984, Pomeroy \& Deibel 1986). Generally, with higher temperatures, summer deposits are of lower quantity and quality because of the dominance of primary production by slowly sinking nanoplankton, rapid decomposition within the pelagic food web, and high zooplankton grazing rates (Malone 1980, Durbin \& Durbin 1981, Smetacek 1984, Hargrave \& Phillips 1986, Pomeroy \& Deibel 1986).

Given this seasonal cycle of detrital sedimentation, and increasing benthic metabolic demand as temperatures increase in coastal waters (Nixon et al. 1976, Rudnick \& Oviatt 1986), the balance of benthic food input and demand may shift seasonally, with winter and spring surpluses and summer deficits. Deficits may be particularly acute for those benthos that feed at the sediment-water interface and depend on fresh inputs. Not only are phytodetrital inputs to this thin, flocculent 
layer temporally variable, but the residence time of organic matter is short because of the layer's small size and losses to mineralization and burial.

In contrast, the food resources of subsurface feeders (probably below the top 1 or $2 \mathrm{~mm}$ for meiobenthos) are far more stable because they have access to and assimilate a portion of the buried pool of older organic matter. As emphasized by Levinton (1972) and supported by the results of this study, the temporal vagaries of phytodetrital inputs are buffered by the large size of this pool and time lags in the mineralization of fresh inputs (Rudnick \& Oviatt 1986). Such an external nutritional reserve is particularly important for meiobenthos and small macrobenthos which lack large internal reserves. Indeed, the most abundant macrobenthos in Narragansett Bay muds are small subsurface feeders (Grassle et al. 1985), such as Mediomastus ambiseta (averaging $10 \mu \mathrm{g} C$ per individual), which had a mean specific activity of only 1.1 DPM ( $\mu \mathrm{g} \mathrm{C})^{-1}$ on 23 May. Although the interpretation of this low value is complicated by this polychaete's 0.5 to $2 \mathrm{~cm}$ feeding depth, it is indicative of the assimilation of old organic carbon.

Given the coincidence of surface and subsurface feeding assemblages, competition between the assemblages may exist for phytodetrital deposits; subsurface fauna would be negatively affected by rapid mineralization of flocculent particles on the sediment surface, while surface fauna would suffer by rapid particle burial and compaction. Experimental evidence that such negative interactions occur, and can be more important than predation or physical disturbance, has been presented by Alongi \& Tenore (1985); additions of a subsurface feeding polychaete decreased surface meiobenthic abundance and additions of an epibenthic harpacticoid copepod decreased polychaete growth.

The contrast in food resource stability which I have inferred between surface and subsurface meiobenthos (and presumably macrobenthos as well) has previously been hypothesized to exist between suspension-feeding benthic communities and deposit-feeding communities in horizontal space (Levinton 1972) and also to exist at a given location with time, as suspension and surface deposit feeders dominate early successional stages and subsurface feeders dominate more mature stages (McCall 1977, Rhoads et al. 1978). The findings of this study support and augment these ideas, suggesting that such a dichotomy can occur along the vertical axis of a single soft-bottom habitat.

Acknowledgements. I thank all of the personnel of MERL for their efforts in support of this study. Particular thanks go to Candace Oviatt for her help in planning and coordinating the study and Jeffrey Frithsen for helping to sort and clean tens of thousands of animals as well as for identifying harpacticoid copepods. Dominique Mertens assisted with the combustion of fauna and sediment. Helpful comments on manuscript drafts were provided by P. Doering, R. Elmgren, J. Frithsen, R. Howarth, H. P. Jeffries, J. Kelly, S. Levine, G. Lopez, A. Morin, and C. Oviatt. This research was a portion of my dissertation, presented to the University of Rhode Island. The complete data set of the radiocarbon study can be found in this dissertation (Rudnick 1984). Support was provided by the University of Rhode Island, the United States Environmental Protection Agency (grant CR807795-01), and the Ecosystems Research Center of Cornell University.

\section{LITERATURE CITED}

Aller, R. C. (1982). The effects of macrobenthos on chemical properties of marine sediment and overlying water. In: McCall, P. L., Tevesz, M. J. S. (eds.) Animal-sediment relations. Plenum Press, New York, p. 53-102

Alongi, D. M., Tenore, K. R. (1985). Effects of detritus supply on trophic relationships within experimental benthic food webs. I. Meiofauna-polychaete (Capitella capitata [type I] Fabricius) interactions. J. exp. mar. Biol. Ecol. 88: 153-166

Benoit, G. J., Turekian, K. K., Benninger, L. K. (1979). Radiocarbon dating of a core from Long Island Sound. Estuar. coast. mar. Sci. 9: 171-180

Billet, D. S. M., Lampitt, R. S., Rice, A. L., Mantoura, R. F. C. (1983). Seasonal sedimentation of phytoplankton to the deep-sea benthos. Nature, Lond. 302: 520-522

Bowen, R. A., St. Onge, J. M., Colton, J. B. Jr., Price, C. A. (1972). Density-gradient centrifugation as an aid to sorting planktonic organisms. I. Gradient materials. Mar. Biol. 14: 242-247

Cammen, L. M. (1980). The significance of microbial carbon in the nutrition of the deposit feeding polychaete Nereis succinea. Mar. Biol. 61: 9-20

Conover, R. J., Francis, V. (1973). The use of radioactive isotopes to measure the transfer of materials in aquatic food chains. Mar. Biol. 18: 272-283

Copping, A. E., Lorenzen, C. J. (1980). Carbon budget of a phytoplankton-herbivore system with carbon-14 as a tracer. Limnol. Oceanogr. 25: 873-882

Cronin, J. R., Morris, R. J. (1983). Rapid formation of humic material from diatom detritus. In: Suess, E., Thiede, J. (eds.) Coastal upwelling: it's sediment record. Part A. Plenum Press, New York, p. 485-496

Coull, B. C., Bell, S. S. (1979). Perspectives of marine meiofaunal ecology. In: Livingston, R. J. (ed.) Ecological processes in coastal and marine systems. Plenum Press, New York, p. 189-216

Durbin, A. G., Durbin, E. G. (1981). Standing stock and estimated production rates of phytoplankton and zooplankton in Narragansett Bay, Rhode Island. Estuaries 4: 24-41

Elmgren, R. (1978). Structure and dynamics of Baltic benthos communities, with particular reference to the relationship between macro- and meiofauna. Kieler Meeresforsch. Sonderh. 4: 1-22

Frithsen, J. B. (1984). Ecological studies of benthic meiofauna in mesocosms. Ph. D. dissertation, University of Rhode Island, Kingston

Frithsen, J. B, Rudnick, D. T., Elmgren, R. (1983). A new flowthrough corer for the quantitative sampling of surface sediments. Hydrobiologia 99: 75-79

Fry, B., Arnold, C. (1982). Rapid ${ }^{13} \mathrm{C} /{ }^{12} \mathrm{C}$ turnover during growth of brown shrimp. Oecologia (Berl.) 54: 200-204

Fry, B., Sherr, E. B. (1984). ${ }^{13} \mathrm{C}$ measurements as indicators of carbon flow in marine and freshwater ecosystems. Contr. mar. Sci. 27: 13-47 
Gearing, J. N., Gearing, P. J., Rudnick, D. T., Requejo, A. G., Hutchins, M. J. (1984). Isotopic variability of organic carbon in a phytoplankton-based, temperature estuary. Geochim. Cosmochim. Acta 48: 1089-1098

Grant, J., Hargrave, B. T. (1987). Benthic metabolism and the quality of sediment organic carbon. Biol. Oceanogr. 4: 243-264

Grassle, J. F., Elmgren, R., Grassle, J. P. (1981). Response of benthic communities in MERL experimental ecosystems to low level chronic additions of no. 2 fuel oil. Mar. environ. Res. 4: 279-297

Grassle, J. F., Grassle, J. P., Brown-Leger, L. S., Petrecca, R. F., Copley, N. J. (1985). Subtidal macrobenthos of Narragansett Bay. Field and mesocosm studies of the effects of eutrophication and organic input on benthic populations. In: Gray, J. S., Christiansen, M. E. (eds.) Marine biology of polar regions and effects of stress on marine organisms. John Wiley, New York, p. 421-434

Grice, G. D., Reeve, M. R. (eds.) (1982). Marine mesocosms. Springer-Verlag, New York

Hargrave, B. T., Phillips, G. A. (1986). Dynamics of the benthic food web in St. Georges Bay, southern Gulf of St. Lawrence. Mar. Ecol. Prog. Ser. 31: 277-294

Hicks, G. R. F., Coull, B. C. (1983). The ecology of marine meiobenthic harpacticoid copepods. Oceanogr. mar. Biol. A. Rev. 21: $67-175$

Hobbie, J. E., Cole, J. J. (1984). Response of a detrital food web to eutrophication. Bull. mar. Sci. 35: 357-363

Howarth, R. W., Hobbie, J. E. (1982). The regulation of decomposition and heterotrophic microbial activity in salt marsh soils: a review. In: Kennedy, V. S. (ed.) Estuarine comparisons. Academic Press, New York, p. 183-207

Howarth, R. W., Teal, J. M. (1980). Energy flow in a salt marsh ecosystem: the role of reduced inorganic sulfur compounds. Am. Nat. 116: 862-872

Hunt, C. D., Smith, D. L. (1983). Remobilization of metals from polluted marine sediments. Can. J. Fish. Aquat. Sci., Suppl. 2: 132-142

Jensen, P. (1983). Meiofaunal abundance and vertical zonation in a sublittoral soft bottom, with a test of the Haps corer. Mar. Biol. 74: 319-326

Johnson, R. G. (1974), Particulate matter at the sedimentwater interface in coastal environments. J. mar. Res. 32: 313-330

de Jonge, V. N., Bouwman, L. A. (1977). A simple density separation technique for quantitative isolation of meiobenthos using colloidal silica Ludox-TM. Mar. Biol. 42: 143-148

Jørgensen, B. B. (1977). Distribution of colorless sulfur bacteria (Beggiatoa spp.) in a coastal marine sediment. Mar. Biol. 41: 19-28

Jørgensen, B. B., Revsbech, N. P. (1985). Diffusive boundary layers and the oxygen uptake of sediments and detritus. Limnol. Oceanogr. 30: 111-122

Kelly, J. R. (1983). Benthic-pelagic coupling in Narragansett Bay. $\mathrm{Ph}$. D. dissertation, University of Rhode Island, Kingston

Kelly, J. R., Nixon, S. W. (1984). Experimental studies of the effect of organic deposition on the metabolism of a coastal marine bottom cummunity. Mar. Ecol. Prog. Ser. 17: $157-169$

Lampert, W. (1975). A tracer study on the carbon turnover of Daphnia pulex. Verh. int. Ver. Limnol. 19: 2913-2921

Lee, J. J., Tietjen, J. H., Stone, R. J., Muller, W. A., McEnery, M., Saks, N., Mastropaolo, C., Kennedy, E. (1971). Effects of environmental stress on the community structure, productivity, energy flow, and mineral cycling in salt marsh epiphytic communities. In: Nelson, D. J. (ed.) Proceedings of the third national symposium on radioecology. Vol. 2 United States Atomic Energy Commission and The Ecological Society of America, Oak Ridge, p. 816-828

Levinton, J. S. (1972). Stability and trophic structure in deposit feeding and suspension feeding communities. Am. Nat. 106: $472-486$

Lopez, G. R., Levinton, J. S. (1987). Ecology of deposit-feeding animals in marine sediments. Q. Rev. Biol. 62: 235-260

Luedtke, N. A., Bender. M. L. (1979). Tracer study of sediment - water interactions in estuaries. Estuar. coast. mar. Sci. 9: 643-651

Malone, T. C. (1980). Size-fractionated primary productivity of marine phytoplankton. In: Falkowski, P. J. (ed.) Primary productivity in the sea. Plenum Press, New York, p. 301-319

Marshall, N. (1972). Interstitial community and sediments of shoal benthic environments. Geol. Soc. Am. Mem. 133: 409-415

McCall, P. L. (1977). Community patterns and adaptive strategies of the infaunal benthos of Long Island Sound. J. mar. Res. 35: 221-266

Moore, H. B. (1931). The muds of the Clyde Sea area. III. Chemical and physical conditions; rate and nature of sedimentation; and fauna. J. mar. biol. Ass. U. K. 17: $325-358$

Nixon, S. W., Oviatt, C. A., Hale, S. S. (1976). Nitrogen regeneration and the metabolism of coastal marine bottom communities. In: Anderson, J. M., MacFadyen, A. (ed.) The role of terrestrial and aquatic organisms in decomposition processes. Blackwell Scientific Publications, Oxford, p. $269-283$

Oviatt, C. A. (1981). Effects of different mixing schedules on phytoplankton, zooplankton and nutrients in marine microcosms. Mar. Ecol. Prog. Ser. 4: 57-67

Oviatt, C. A., Nixon, S. W. (1975). Sediment resuspension and deposition in Narragansett Bay. Estuar. coast. mar. Sci. 3: 201-217

Oviatt, C. A., Buckley, B. A., Nixon, S. W. (1981). Annual phytoplankton metabolism in Narragansett Bay calculated from field measurements and microcosm observations. Estuaries 4: 167-175

Oviatt, C. A., Keller, A. A., Sampou, P. A., Beatty, L. L. (1986). Patterns of productivity during eutrophication: a mesocosm experiment. Mar. Ecol. Prog. Ser. 28: 69-80

Pilson, M. E. Q. (1985). Annual cycles of nutrients and chlorophyll in Narragansett Bay, Rhode Island. J. mar. Res. 43: 849-873

Pilson, M. E. Q., Oviatt, C. A., Nixon, S. W. (1980). Annual nutrient cycles in a marine microcosm. In: Giesy, J. P. (ed.) Microcosms in ecological research. Department of Energy Symposium Series 52, CONF-781101. National Technical Information Service, Springfield, Virginia, p. 753-778

Pomeroy, L. R., Deibel, D. (1986). Temperature regulation of bacterial activity during the spring bloom in Newfoundland coastal waters. Science 233: 359-361

Rhoads, D. C. (1974). Organism-sediment relations on the muddy sea floor. Oceanogr. mar. biol. A. Rev. 12: 263-300

Rhoads, D. C., McCall, P. L., Yingst, J. Y. (1978). Disturbance and production on the estuarine seafloor. Am. Sci. 66: 577-586

Rhoads, D. C., Boyer, L. F., Welsh, B. L., Hampson, G. R. (1984). Seasonal dynamics of detritus in the benthic turbidity zone (BTZ); implications for bottom-rack molluscan mariculture. Bull. mar. Sci. 35: 536-549

Rice, D. L. (1982). The detritus nitrogen problem: new observations and perspectives from organic geochemistry. Mar. Ecol. Prog. Ser. 9: 153-162 
Rudnick, D. T. (1984). Seasonality of community structure and carbon flow in Narragansett Bay sediments. Ph. D. dissertation, University of Rhode Island, Kingston

Rudnick, D. T., Oviatt, C. A. (1986). Seasonal lags between organic carbon deposition and mineralization in marine sediments. J. mar. Res. 44: 815-837

Rudnick, D. T., Elmgren, R., Frithsen, J. B. (1985). Meiofaunal prominence and benthic seasonality in a coastal marine ecosystem. Oecologia (Berl.) 67: 157-168

Santschi, P. H., Carson, S., Li., Y.-H. (1982). Natural radionuclides as tracers for geochemical processes in MERL mesocosms and Narragansett Bay. In: Grice, G. D., Reeve, M. R. (eds.) Marine mesocosms. Springer-Verlag, New York, p. 97-109

Smetacek, V. (1984). The supply of food to the benthos. In: Fasham, M. J. R. (ed.) Flows of energy and materials in marine ecosystems. Plenum Press, New York, p. 517-547

Sorokin, Y. I. (1966). Carbon-14 method in the study of the nutrition of aquatic animals. Int. Revue ges. Hydrobiol. 51: 209-224

Tenore, K. R., Cammen, L., Findlay, S. E. G., Phillips, N. (1982). Perspectives of research on detritus: do factors controlling the availability of detritus depend on its source? J. mar. Res. 40: 473-490

Tietjen, J. H. (1969). The ecology of shallow water meiofauna in two New England estuaries. Oecologia (Berl.) 2: 251-291

Warwick, R. M., Gee, J. M. (1984). Community structure of estuarine meiobenthos. Mar. Ecol. Prog. Ser. 18: 97-111

Westrich, J. T., Berner, R. A. (1984). The role of sedimentary organic matter in bacterial sulfate reduction: the $\mathrm{G}$ model tested. Limnol. Oceanogr. 29: 236-249

Wetzel, R. L. (1976). Carbon resources of a benthic salt marsh invertebrate, Nassarius obseletus Say (Mollusca: Nassaridae). In: Wiley, M. (ed.) Estuarine processes, Vol. 2. Academic Press, New York, p. 293-308

Whitlatch, R. B. (1980). Patterns of resource utilization and coexistence in marine intertidal deposit-feeding communities. J. mar. Res. 38: 743-765

Widbom, B., Elmgren, R. (1988). Response of benthic meiofauna to nutrient enrichment of experimental marine ecosystems. Mar. Ecol. Prog. Ser. 42: 257-268

Young, D. K. (1971). Effects of infauna on the sediment and seston of a subtidal environment. Vie et Milieu, Suppl. 22: $557-571$

This article was submitted to the editor; it was accepted for printing on September 9, 1988 